DOI: https://doi.org/10.31392/NPU-nc.series9.2019.19.02

UDC: 81 '1-119“312”(045)

\section{Olena O. Balaban}

National Pedagogical Dragomanov University, Kyiv, Ukraine

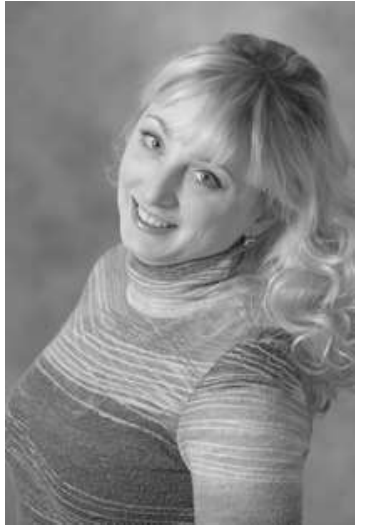

\title{
CONCEPT MODERN WOMAN AS COGNITIVE AND SEMANTIC UNIVERSAL IN RELATED LANGUAGES
}

\section{Bibliographic Description:}

Balaban, O. O. (2019). Concept Modern Woman as Cognitive and Semantic Universal in Related Languages. Scientific Journal of National Pedagogical Dragomanov University. Series 9. Current Trends in Language Development, 19. P. 17-35. DOI: https://doi.org/10.31392/NPU-nc.series9.2019.19.02

\section{Abstract}

This typological study presents the description of the concept Modern Woman as cognitive and semantic universal in related languages. This is carried out due to the description of the macrostructure of the concept that predetermines the distribution of selected characteristics according to structural macrocomponent of the concept - imaginative, informational component and interpretation field; categorical structure of the concept, which presents the cognitive hierarchy of the classification criteria, conceptualize the consequent subject or phenomenon; the field organization of the concept. There were analyzed the approaches to the definition of the term "concept" at first, including semantic, cognitive and cultural ones.

Basing onto the typology of concepts suggested by Sternin, who identifies three main types of concepts: concepts-representations, concepts and gestalts, we decided to make an attempt to analyze the categorical structure of the concept-prototype, concept-frame, concept-scenario / script and concept-scheme in related languages, but we have done it on the example of fiction by the contemporary British writer Cecilia Ahern "The Time of my Life" and its translations into Russian and Ukrainian.

Identification of cognitive classification features of the concept-prototype "Modern Woman" allowed us to note the following features in related languages: physiological features mark the conceptual features of biological sex, age, appearance; status-role features indicate social status, status and role in society; functional features indicate the type of activity or occupation; relational features position of a person in relation to other persons or groups of persons; mental and functional features that indicate emotional state, mental abilities, health status, etc.; axiological features that characterize the internal properties of a person, 
character traits, demeanor; affective and emotive signs indicate an emotional attitude to the subject: approvalcondemnation / displeasure, acceptance-rejection, irritation, irony, etc. The main slots of the concept frame "Modern Woman" are beauty, fashion, love and sex, work and life, lifestyle, news and politics, career, psychology and relationships. Concepts-scenarios and concepts-schemes are also represented by the corresponding episodes and images. So, the concept is perceived as the basic unit of human memory, which structures the mental space of a person, it is cognitive and semantic universal onto the cognitive level in the formation of lexical meaning in such related languages as English, Ukrainian, Russian.

Key words: concept, modern woman, concept prototype, concept frame, concept scenario (script), concept diagram, cognitive-semantic-universal.

\section{Introduction.}

As Lakoff and Johnson (2003) noted in their famous work "Metaphors we live by" concepts control our lives, structure our feelings, behaviour and attitude, and the conceptual system itself is a metaphorical one. According to the scientists, language is an important source of data on the system of human thinking, and metaphors reflect our attitude, thinking and activity too. The term "concept" was borrowed from cognitive science and chosen as the basis in cognitive linguistics while studying semantic space of the language, due to which you can get an impression of the structure of knowledge. It is understood by the majority of cognitive scientists (S. Popova, Y. Sternin, V. Maslova, O. Kubryakova, S. Zhabotinska etc.) as a mental image behind the language sign, that is, the designated language sign.

It is accepted to distinguish the following approaches to the interpretation of the term "concept": semantic, cognitive and cultural. The semantic approach is represented by the point of view that the concept exists for a limited dictionary meaning and is considered as an algebraic expression of the meaning. In general, representatives of this trend understand the concept as the whole potential of the word meaning together with its connotative element (M. Boldyrev (2000), A. Babushkin (1996) et al.) and consider the concept within the framework of such linguistic trend as cognitive semantics. Babushkin developed a classification of concepts onto the lexico-phraseological basis. His research interests are focused on lexical and phraseological concepts mostly. This distinction is made on the basis of dictionary definitions of concept. Babushkin (1996) defines the concept as any discrete unit of collective consciousness that reflects the subject of the real or ideal world and is saved in the national memory of native speakers in the form of a cognized verbally designated substrate. The types of concepts identified by Boldyrev have much in common with the types of concepts proposed by Babushkin in fact, although Boldyrev uses other terms in most cases. The classification of Babushkin, Boldyrev complements the class of grammatical concepts, and also divides the concepts according to the content and degree of abstraction.

Adherents of the cognitive approach to understanding the essence of the concept refer it to the phenomena of mental nature. In this way Popova, Sternin (2007) and other representatives classify the concept as mental phenomena, defining it as a global mental unit, "a quantum of structured knowledge". Sternin (2007) treats the concept as "a complex mental unit, which in the process of mental activity is returned by different parties, actualising in the process of mental activity its various features and layers" and provides a model of the concept in terms of the nucleus and periphery. As a result of the analysis of the data obtained during the psycholinguistic experiment, the author comes to the conclusion that the nucleus of the concept includes the most vivid image, which is of an individual sensual nature and encodes the concept for mental operations, referring to Sternin. The nucleus of the concept has a bright personal colour, as the visual-sensual image is formed from personal experience. Thus, the nucleus of the concept is its basic layer and a set of cognitive layers and cognitive segments forms their cognitive characteristics in total (Popova, Sternin, 2007). 
Field model of the concept developed by Popova and Sternin is as follows: 1) nucleus is a visual-sensual image; 2) the basic layers are different in the degree of abstraction of the conceptual signs and therefore they are at different distances from the nucleus, having different brightness with respect to each other; 3) interpretative field of the concept, reflecting the evaluation and interpretation of the content of the nucleus and conceptual signs in the form of mind-sets, affirmations, different kinds of stereotypes belonging to the national, group or individual consciousness (Popova, Sternin, 2007).

Quite the opposite third direction of the study involves linguacultural approach going from cultural to individual consciousness. Representatives of this approach should be considered (V. Karasik, Yu. Stepanov, V. Neroznak, V. Krasnykh, V. Maslova, N. Alefirenko etc.). Linguacultural approach allows grasping the deeper essence of concepts, formed in the collective linguistic consciousness of the nation, to reveal the system of values and evaluations, the development of which was influenced by cultural, linguistic and social experience of a particular sociocultural community finally. This approach focuses onto the cultural concepts.

\section{Aim and Objectives.}

The aim of the article is to describe the concept as a cognitive and semantic universal in related languages.

The achievement of the common goal included the following objectives: 1) to consider the concept as the basic unit of human memory and cognitive and semantic universal in related languages; 2) to analyse the categorical structure of the concept of "modern woman" in English, Ukrainian, Russian.

\section{Methodology.}

Among the methods that are used in modern cognitive linguistics to describe the concept are: 1) the description of the macrostructure of the concept that presupposes the distribution of the selected features onto the structural macro components of the concept image-bearing, informational component and the interpretation field; 2) the description of the categorical structure of the concept that conceptualizes the relevant object or phenomenon is given concerning the hierarchy of cognitive classification features; 3 ) the description of the field organization of the concept. At this stage, there are the cognitive classification features that make up the nucleus, close and distant periphery of the concept is distinguished, and the content of the concept is represented in the form of the field structure.

\section{Typology of Concepts in Related Languages.}

As a result, a set of concepts as structures of representation of human knowledge about the world is determined by the fact that the concepts are not of the same type in the way of their organization. Sternin distinguishes the following structural types of concepts: single-level, which includes only the perceptual nucleus, one basic layer (object images (M. Boldyrev), concepts-representation); multi-level, which consist of several cognitive layers, differing in the level of abstraction and gradually layered onto the basic layer; segmental represent one basic layer, surrounded by several segments, which are equal in the degree of abstraction (Popova, Sternin, 2007). These layers are called cognitive because they reflect a certain result of knowledge of the outer world, that is, the result of cognition. The set of the basic layer and additional cognitive features constitute and determine its structure (Popova, Sternin, 2007).

There are different typologies of concepts in modern linguistics. Thus, concepts are distinguished by the degree of concreteness / abstractness of the contents; in terms of 
expression concepts are distinguished as verbalized and non-verbalised within the language; in terms of the degree of stability and frequency of actualization they are classified onto stable (actual) and unstable (irrelevant). In philosophy, the types of concepts are known by their contents and degree of abstraction - representations and concepts, supplemented by representations (generalised perceptual images of objects or phenomena), schemes (spatial and contour graphic thinking image), frames (multicomponent concept, three-dimensional representation, a set of standard knowledge about an object or phenomenon), scenarios (a sequence of stereotyped episodes) and a number of other types. Babushkin (1996) developed the typology of concepts, including mental pictures, diagrams, frames, scenarios, kaleidoscopic and logically designed concepts. Sternin distinguishes three main types of concepts: concepts-representations, concepts-notions and gestalts. He refers to the representations generalised sensory-visual images of objects or phenomena (apple). Concepts-representations are objectified in the language by lexical units of concrete semantics mainly. Concepts-notions are considered as the idea of the most common, essential features of objects or phenomena, the result of a rational reflection of the main, essential features of the object. And concepts-gestalts are considered as complex, integral functional structures, which order the variety of individual phenomena in consciousness (school, love, game) (Popova, Sternin, 2007: 61). Taking into account his typology, let's consider the concept-prototype, concept-frame, concept-scenario (script) and conceptscheme in related languages.

\subsection{Concept-Prototype in Related Languages.}

One of the trends of cognitive linguistics is prototypical semantics or the theory of prototypes. The theory of prototypes in linguistics is presented by the researches onto different levels: semantical (Ch. Fillmore, A. Chenki, O. Kubryakova, K. Rahilina etc.), grammatical (M. Boldyrev, O. Bondarko etc.) and derivational (G. Kustova etc.). Unlike traditional semasiology there exists "the world of things and the world of ideas, cognitive experts believe that the outer world is reflected in human consciousness in the form of certain categories, which are divided into natural and semantical, and within each category there are its typical representatives which Rosch calls prototypes. The prototype includes the most typical features for a particular category and is formed onto general qualities inherited by their representatives. Consequently, the set of the most important features forms the centre of the category opposed to the periphery, where the less important features are located.

Regarding the definition of the term "prototype", its definitions are approximately within the same domain: a reference version, a reference image etc. Thus, O. Hamray perceives the prototype as a reference version of a certain invariant systemic object which is characterized by the highest concentration of specific features of the object (Hamray, 2008). For Wierzbicka (1996) prototypes are idealised, reference images, mental formations that do not reflect the essential properties of the representation of the object. In her analysis, the researcher is based onto the model "sense - text". The "Concise Dictionary of Cognitive Terms" notes that the prototype is "a concrete or abstract mental image of objects belonging to a certain category [...] and if it helps people to perceive the reality: a member of category which is closer to the image, will be evaluated as the best prototype of its class or the opposite one among all the rest" (Concise Dictionary of Cognitive Terms, 1996: 145).

Oppositionists of this theory insist that this approach does not characterize specific phenomena, but believe that the prototype functions in communication as a "good example". They are also convinced that concepts are hardly presented through prototypes in general and people often operate with accurate definitions (Demyankov, 2001). 
The structure of these "typical" categories has a radial structure, according to Rosch (1973), in which central (nucleus) position is occupied by prototype, and the other members are removed from it at a shorter distance, and the further a certain component is located, the more questionable is its categorical affiliation, the degree of reliability about it decreases and more mental effort is spent onto the analysis of its properties. Consequently, the structure of these categories is described in the vector of prototypes and the distance of prototypes, which can be moved to the limits of another category, because there is no clear boundary of categories. Categories are formed in our minds on the basis of two principles: "structuring the world" and "cognitive economy". According to the first principle, categories are formed in the human consciousness not arbitrarily, not on the basis of a random set of features. The combination of defining properties for a particular category has a clear structure and is "an empirical fact represented by the world that is perceived" (Rosch, 1973). For the second principle category captures the world, which is perceived by a man, in the most concise form (Ibid.). The content and structure of such categories are universal, but vary depending on the cultural centre (Ibid.). By the way, prototypes are considered to be the most variable category, since they can change over the time as a result of the acquisition of new representatives of the category.

In general, the concept-prototype "modern woman" is integrated into the macroconcept "woman" using semantic centre certified in the interpretation of this concept is "an adult female human being" [CALD], “лицо, противоположное мужчине по полу" [ТСРЯ], “особа жіночої статі протилежна чоловіку” [АТСУМ] as one of the signs of identification of a woman in the modern world. Among the main possible nominations of the concept in English we observe woman, female, lady, miss, misses; in Ukrainian жінка, жіночка, пані; in Russian женщина, дама, госпожа etc. It should be noted that using associative experiment the concept "woman" was analysed by Marchuk (2009), the field structure of the concept "woman" was described by Voronina (2015), socio-cultural stereotypes of the concept "woman" was presented by Kalina (2009), paremiological characteristics of the concept "woman" interested Rudyuk (2010), Kutsik and Kolechko (2015) etc. We decided to make an attempt to analyse the categorical structure of this concept-prototype but we decided to do it on the example of the fiction work of the contemporary British writer Cecilia Ahern "The Time of my Life" and its translations into Russian and Ukrainian languages, so consequently we analysed the concept-prototype "modern woman", which is integrated into macroconcept "woman" using the semantic center certified in the interpretation of this concept as "an adult female human being" [CALD], "лицо, противоположное мужчине по полу" [ТСРЯ], “особа жіночої статі протилежна чоловіку" [АТСУМ] as one of the signs of identification of the woman in the modern world.

Identification of cognitive classification features for the concept-prototype "modern woman" allowed to identify the following features in related languages:

1) psychological features mark conceptual features of a biological sex, age, appearance:

(eng.) 'Because I bought it for what's-her-name, that girl you dumped who laughed like a dolphin'. 'Yeah, dolphin-laughing bitch,' he agreed and we smiled (Ahern: 24).

(rus.) - Неудивительно. Я же их подарила этой, как бишь ее, ну, той девице, которую ты бросил. Она еще улыбалась как акула (Ахерн: 30).

(ukr.) - Бо то я подарувала їх тій, не-пригадую-як-ї̈-звуть, дівчині, яку ти покинув і яка сміялася, наче дельфін (Агерн: 30).

In this example, the description of the smile of the girl in all three languages expressed by the comparison as one of the most common stylistic figures and techniques of conceptualization of reality ((eng.) to laugh like a dolphin, (rus.) улььбаться как акула, 
(ukr.) сміятися, наче дельфін)). The logical-semantic model of this example is as follows: animal $\rightarrow$ human (trait) + logical multiplication (conjunction: $a^{\wedge} b$ ). From the semantic point of view, there is a replacement of the archiseme "animal", "животное", "тварина" onto "person", «человек», “людина" and multiplication is provided by adding differential semes "large", "smooth", “pointed mouth", “большой”, “широкий”, “оскалистый”, “великий”, "розлогий", "вищир".

2) status-role signs indicate social status, status and role in society:

(eng.) What I was doing down there shall remain private but it was raining hard, I was wearing a beige trench coat and after mourning the boss of a perfect boyfriend over too many tequilas, I was doing my best to channel Audrey Hepburn by chasing the animal and calling out "Cat!" in a clear and unique, yet distressed tone (Ahern: 4-5).

(rus.) А уж что я делала вечером в том переулке под проливным дождем -мое личное дело. В бежевом плаще, да в бежевом плаще и после изрядного количества выпитой текилы, в глубоком трауре по утраченном бойфренду, я попыталась вести себя точно так, как Одри Хепберн в "Завтрак у Тифани”, взывала горячо и страстно "Кис-кис!", чисто, трепетно и безнадежно (Ахерн: 11).

(ukr.) Не розповідатиму про те, що я там робила, але йшов густий дощ, я мала на собі довгий бежевий непромокальний плащ, як в Одрі Гепберн у "Сніданку в Тіфані”, $і$ оплакавши свого чудового бойфренда з багатьма пориіями текіли, я вирішила відволіктися в спрямувати увагу на знайдене кошеня й покликала його: "Киџю, киџь!"” (Агерн: 14).

This example shows a social status of the main character of the novel as a single woman and to describe her emotional state after parting with her boyfriend. The sense verbs which are used in a figurative sense (eng.) to mourn - to feel or express sadness, especially because of someone's death [CALD]; (rus.) находиться в трауре - находиться, прибывать в состоянии скорби по умершему (а также по поводу какого-нибудь бедствия, катострофы), выражающееся в ношении особой одежды [TCPЯ]; (ukr.) оплакувати - плакати з приводу чиєї-небудь смерті, тяжкої втрати, нещастя тощо.; виражати свій сум, горе з якого-небудь приводу; сумувати [АТСУМ]. The logicalsemantic model of this example is as follows: human (emotional state) + logical multiplication (conjunction: $a^{\wedge} b$ ).

3) functional features indicate the type of activity or occupation:

(eng.) It was a place more worshipped than any other in the building, more than the coffee machine, more than the exit doors at six p.m., most certainly more than the chair before the desk of Edna Larson - the boss lady - who ate good intentions like a broken dispenser that swallowed your coins but failed to spit out the bar of chocolate (Ahern: 2).

(rus.) Место это, подобно всякому святилищу, где курят фимиам, почитаемо более, чем любое другое в нашем здании. Более, чем кофе-машина, чем дверь на улииу в шесть вечера, и много более, чем стул у стола Эдны Ларсон - нашей начальничь, которая пожирает благие намерения, как неисправный автомат, что заглатывает монеты, но отказывается выплюнуть взамен плитку шоколада (Ахерн: 8).

(ukr.) Це місче шанували більше, аніж будь-яке інше в будівлі, більше ніж кавоварку, більше аніж двері виходу, що відчинялися о шостій годині вечора, й, безперечно, набагато більше, ніж стілець перед письмовим столом Едні Ларсон, жінки-боса, яка поглинала добрі наміри, як ото зламаний торговий автомат ковтає ваші монети, але виплюнути вам плитку шоколаду неспроможний (Агерн: 11-12).

This example describes the nature of the heroine's chief in all three languages by means of the metaphor (eng.) to eat intentions; (rus.) пожирать намерения; (ukr.) поглинати наміри). The logical-semantic model of this example is as follows: humain 
(character trait) $\rightarrow$ abstract notion + logical multiplication (conjunction: $\left.a^{\wedge} b\right)$. From the semantic point of view, there is a replacement of the archeme "person", «человек», "людина" to "abstruct notion", "абстрактное понятие", "абстрактне поняття" and multiplication is provided by the addition of differential semes "to destroy", "fully", "absolutelly", "уничтожать”, “полностью”, “абсолютно”, “знищувати", “повністю”, "абсолютно". persons:

4) relational signs position of the person in relation to other persons or group of

(eng.) When I had enforced my opinion at work I'd been called a bitch by my male counterparts (Ahern: 5).

(rus.) A на работе, когда я в кои-то веки настояла на своем мнении, коллегимужчины сказали, что я стерва (Ахерн: 11).

(ukr.) Коли мені вдалося накинути колегам свою думку на службі, то один з них назвав мене курвою (Агерн, с. 14).

This example presents the attempt to characterize the main character with the help of an informal noun with a negative connotation in all three languages (eng.) bitch - an unkind or unpleasant woman [CALD]; (rus.) стерва - подлая женщина, негодяйка [TCPя]; (ukr.) курва - гуляща жінка, повія [АТСУМ]). The logical-semantic model of this example is as follows: humain (character trait) + logical addition. Semantically there remains archiseme "person", "человек", "людина" and differential semes are added "unkind, "unpleasant", "подлый”, "гуляща".

5) mental and functional signs indicate emotional state, mental abilities, health status etc.:

(eng.) I felt a tiny rush of warmth for him, because all of a sudden he looked old (Ahern: 32).

(rus.). Я испытала кромечный прилив нежности, вдруг увидев, как сильно он постарел (Ахерн: 38).

(ukr.) Я відчула напад теплого почуття до нього, бо несподівано він здався мені старим (Агерн: 14).

Emotional state of the main heroine to his father again is reflected with the help of metaphorical transference in all three languages (eng.) a rush of warmth; (rus.) прилив нежности; (ukr.) напад почуття. The transference occurs by means of replacing archiseme "action", “действие", "дія" to "abstract notion", “абстрактное понятие", "абстрактне поняття" (eng.) rush - an act of suddenly moving somewhere quickly $\rightarrow$ a sudden strong emotion or physical feeling [CALD]; (rus.) прилив - периодически повторяющееся действие поднятие уровня открытого моря в течение суток $\rightarrow$ скопление чего-н. движущегося, приток [ТСРЯ]; (ukr.) наnad - дія за значенням напасти, нападати, атакувати $\rightarrow$ момент загострення, посилення чого-небудь; приступ [АТСУМ]) and adding the differential seme "feeling", «чувство», "почуття". The logicalsemantic model of this example is as follows: action (humain) $\rightarrow$ abstract concept + logical multiplication (conjunction: $a^{\wedge} b$ ).

(eng.) Mum almost lit up like a framework at the sight of her precious son making his way to her (Ahern: 27).

(rus.) Мамина ульбкка засверкала подобно фейерверку при виде ее драгоченного сыночка (Ахерн: 33).

(ukr.) Він підійшов до матері поперед мене, й вона спалахнула, наче фееєрверк, коли побачила свого дорогочінного синочка (Агерн: 33).

Metaphorical expressions (eng.) mum lit up like a framework, (rus.) мамина улыбка засверкала подобно фейерверку, (ukr.) вона спалахнула, наче феєрверк is strengthened 
by the comparison. The original concepts of verbs (eng.) to light up - to produce light that makes an object or area bright or easy to see, (rus.) сверкать - ярко сиять переливчастым светом, (ukr.) спалахнути - раптово i швидко загоратися яскравим полум'ям, займатися слугували основою для похідних - (eng.) to have a happy look [CALD], (rus.) блестеть, выражая сильные чувства, эмоции (например, страсть) (обачно о глазах) [ТСРЯ], (ukr.) раптово пройматися якимсь сильним почуттям, сильно збуджуватися, дратуватися, гніватися (про людину) [АТСУМ] and the addition of new differential semes "hарру", “сильный”, “эмоции", “чувства", “сильний”, "почуття". The logical-semantic model of this example is as follows: abstract concept $\rightarrow$ humain (emotional state) + addition.

6) axiological features characterize the internal properties of a person, character traits, behaviour:

(eng.) 'It's just an expression. For doing something... amazing'. I tried to hold back on the bitter sarcastic tone that was just dying to get out. It was on the sidelines warming up, begging me to let it go on as a substitute for politeness and tolerance (Ahern: 37).

(rus.) - Просто выражение такое. В смысле, награду за такие великие заслуги. Я пыталась обуздать злой сарказм, который так и рвался на игровое поле. Он разогревался за боковой линией, умоляя меня выпустить его на замену вежливости и терпимости (Ахерн: 43).

(ukr.) - Це, власне, образний вислів. Вас не могли не нагородити, адже ви вчинили... щуось надзвичайне. Я доклала зусиль, щоб стримати гіркий сарказм, який помер, щойно народившись. Він розігрівався за бічною лінією, благаючи мене, щоб я дозволила йому ввійти у гру, змінити на чемність і толерантність (Агерн: 40).

To emphasise the liveliness and restlessness of the character of the main character we again deal with the metaphor in three languages that are studied ((eng.) bitter sarcastic tone was trying to get out; (rus.) горький сарказм рвался; (ukr.) гіркий сарказм помер). Тhе transference is due to the replacement of the archiseme "person", "человек", "людина" на "abstract notion", "абстрактное понятие", "абстрактне поняття" as well as we observe the addition of differential semes "emotion", «эмоция», "емоція". The logical-semantic model of this example is as follows: humain $\rightarrow$ abstract notion (emotional feeling) + logical multiplication (conjunction: $a^{\wedge} b$ ).

7) affective and emotive signs indicate an emotional attitude towards a subject: approval-condemnation/dissatisfaction, acceptance-rejection, irritation, irony etc.:

(eng.) She sat quietly, not looking at Philip and probably not listening either while she surveyed my mother's work with her ever disapproving eye (Ahern: 26).

(rus.) Ни жестом, ни словом она не реагировала на то, что говорил Филипп, $u$ скорей всего его не слушала, внимательно и неодобрительно наблюдала за усилиями моей матери (Ахерн: 32).

(ukr.) Вона сиділа спокійно, не дивлячись на Філіпа, й, либонь, не слухала його, бо пильно спостерігала завжди несхвальним оком за тим, що робила моя мати (Агерн: 31).

The epithet describes the emotional state of the mother in the above example in all three languages (англ.) disapproving eye; (рос.) неодобрительно наблюдала; (укр.) спостерігати несхвальним оком. The logical-semantic model of this example is as follows: human (emotional feeling) + logical multiplication (conjunction: $a^{\wedge} b$ ). From the semantic point of view, there is a preservation of the archeme "person", "человек", "людина" and the addition of the differential semes "emotion", "эмоция", "емоція". 


\subsection{Concept-Frame in Related Languages.}

One of the trends of studying the processes of conceptualization of human experience by language means in the mid-twentieth century was frame semantics (Ch. Fillmore, M. Minsky, et al.). Although frame semantics was the first to be used for grammatical description of the language, it later began to function as a means of characterizing the principles of constructing new words and sentences. In general, frame concepts allow to model consciousness and get information about the world.

The introduction of the term "frame" to the general conceptual apparatus in the early 70 of XX c. belongs to Minsky. The researcher defines "frame" as formed in a certain way information data that reflect the acquired experience of knowledge about a certain stereotypical situation, which is perceived quite generally, because it can mean action, image, narration etc. Graphically, the frame scientist proposes to present as a multi-level network consisting of junctions and links between them. The upper, superordinate junctions of the network are clearly defined, because they are formed by the concepts the meaning of which always corresponds to the situation that this frame represents. Below these junctions, onto the subordination levels, there are terminal junctions, these are obligatory components whose verbalization depends onto the speech situation (Minsky, 1979).

Psychologists consider the frame as a fixed system of parameters describing a particular object or event (Selivanova, 1999: 645). Sociologists use this term referring to the concept of Hoffman (associated with the theory of Bateson), according to which "frame" is an analytical basis, support, with which a person is aware of his experience (Hoffman, 2004: 186). Among the pioneering linguists who used the term was Fillmore (1988: 55), who interpreted the conception by Minsky in the framework of generative grammar and grammar case in order to determine the semantic roles of the components of the situation, which are modelled in the mind of the speaker. The concept "frame" is equal in the content to the concept of "case frame" in this aspect, that is, the system of choice of language means associated with the prototype of the scene (or a typical situation). The linguist defines the frame as "special unified constructions or schematizations of the experience" in his further researches (Fillmore, 1988: 53). The evolution of Ch. Fillmore's ideas about the identification of the frame with cognitive structures, the knowledge of which is associated with concepts represented by the words (Fillmore, Baker, 2010:314). The frame also appears as a model of the prototype meaning of the lexical unit, due to which information about the world is identified in the semantics of the sign (Ibid.).

An attempt to generalize the whole variety of interpretations of the term frame in linguistics allowed us to present the following definitions: 1) frame as a system of choice of its language means - grammatical rules, lexical units, language categories which are related to the prototype of the scene (Ch. Fillmore); 2) frame is a set of standardized real and potential knowledge of phenomena that have a complex multi-component structure, an entire view of a multi-level concept (Z. Popova, I. Sternin, A. Babushkin); 3) frame is a cognitive model representing knowledge and assessments which are related to concreate, often repeated situations (F. Ungerer, H. Schmidt); 4) frame as a unit of knowledge is organized around the concept, containing data onto the essential, typical and possible for this concept within a certain culture (T. van Dijk, R. Bogrand, V. Dresler).

However, despite the numerous definitions of the frame, its characteristic features are distinguished depending onto the purpose and objectives of the study, and the main feature is organizational as it was already noted, which allows you to simulate thought processes and identify cognitive structures.

The most productive for our research is the consideration of the frame as a cognitive structure was provided by Bystrov (2016), it a structured information in a certain way, that is 
stored in memory and provides inanimate visual perception and a certain representation of the stereotype situation.

Having analysed the works of scientists in cognitive linguistics devoted to the study of the nature of the frame as an independent cognitive structure, Kolyadenko (2013) notes its following specific features:

1. Frame is a structure of representation of a person's knowledge experience, which connects the mental sphere with the linguistic one. Unlike other types of cognitive units (for example, image), the frame is the semantic framework of the future statement (Ch. Fillmore, G. Andor, et al.). By means of the frame there is a transition of extensional mental unit in a linear verbal structure. The reverse process is observed in the course of information decoding, when the language structure passes through the frame formed by the recipient, unfolds and causes the corresponding images and concepts in his consciousness.

2. Frame is the structure of knowledge representation in the form of a referential scheme of the situation, which is a set of features due to it. It is a set of specific features that is responsible for the identification of each specific situation or denotate in the human consciousness, strengthens the experience of reflecting the segment of reality through its correlation with the unit of the language thesaurus.

3. Frame is a representation of knowledge about a typical situation that can be formally represented through a fixed set of semantic components (junctions or slots) caused by it and the relations between them, the upper levels of the frame always correspond to the situation fixed in the consciousness, and the lower ones containing terminals that can be filled through deepening information about the situation, image-bearing about it. One and the same junction can be a component of different frames, which having combined form a branched network between the frames (Kolyadenko, 2013: 140-141).

The typology of frames in cognitive linguistics is also marked by its diversity. Scientists in cognitive linguistics distinguish the following types of frames:

1) by origin: a) primary, corresponding to the primary schemes of perception and interpretation of events; they allow to localise, perceive, determine an unlimited number of events and give them names; b) secondary, those that transform activities which are conscious in terms of the primary frame system (Hoffman, 2004);

2) in accordance with the concept filling of the frame: a) a static frame is a structure containing knowledge about a certain state of things; b) dynamic (script / script) frame is a structure, which presents procedural knowledge about the course of events (Zhabotinska, 2004);

3) onto the principle of representation of knowledge: a) a static frame is a "packet", "link" schematized human experience; b) dynamic categorical frame reflects the human experience in the process of speech activity as the semantic frame of its discursive activities (Zhabotinska, 2004: 22);

4) onto the type of information which the frame represents: cognitive and semantic, reflecting the specific structure of thinking; cultural, used to provide information about the special elements of culture (Fillmore);

5) onto hierarchical organization: a) simple / basic frames that demonstrate the most general principles of categorisation of verbalized information (Zhabotinska, 2004: 83), in particular the subject (and the very essence that contains a description of its quantitative, existential, locational and temporal parameters); actional (the focus of this type of frame is the interaction of one object with others that are vested in accordance with the nature of the interaction between semantic roles: agent, instrument, patient, the addressee, purpose, cause, effect, result, benefit etc.); possessive (this type of frames demonstrates interdimensional communication; taxonomic (it is the relationship of categorization, within which are generic- 
specific and role relations are united); comparative (it combines essences based on their identities or similarities) (Zhabotinska, 2004, p. 83-84); b) complex frames / comprehensive frames / macroframes which are cognitive structures formed as a result of the integration of several basic frames.

Minsky (1979), the founder of the frame organisation of knowledge, distinguishes the following types of cognitive frames: structures;

- superficial syntactic frames, which are represented by verbal and nominal

- superficial semantic frames that organize the meaning of words, define the participants of the situation, as well as instruments, goals, strategies, results and side effects of their actions;

- thematic frames or scenarios, that are related to specific topics, activities, descriptions of individuals and environments, as well as global issues and strategies that are related to the theme;

- narrative frames (the framework of the typical stories, explanations which are connected with the focus on the narration, characters, plot forms, development, etc. and it is designed to assist the listener in the construction of specific thematic frame).

In our research, we decided to try to build a concept frame "modern woman" on the basis of thematic frameworks that are presented in such world-famous women's glossy magazines as "Cosmopolitan", "Elle", "Vogue" of 2017-2018., which are issued by the various languages (including those that we study: English, Russian, Ukrainian) and contain general thematic materials. In our opinion, this is due to the globalization processes in the world, which unite women from different countries under the auspices of existing trends, sensations or social discourses, as well as the commonality of women's interests, remain more or less stable throughout the existence and development of the women's press.

According to the scholars the main subjects of the women's magazine relate to selfcare, homecare, family life, travelling, career and the formation of a certain lifestyle, characterized by subordination to time cycles (week is divided into weekdays and weekends, in the year there are still holidays and vacation time etc.). These cycles determine the occupation and lifestyle of a modern woman. Three words "career", "beauty" and "boyfriends" defined the concept in the advertisement of all glossy magazines "Cosmopolitan" (Sleptsova, Romah, 2009).

Quite traditional topics of all glossy magazines are fashion, beauty, care about appearance, psychology and problems of relationships, work and life. Such rubrics we met in the above-mentioned glossies as "Cosmopolitan", "Elle", "Vogue". The following headlines are remarkable for such rubrics, which immediately catches the eye and refers the reader to a particular topic. For example, headlines to the topic "Beauty", which is present in the model magazine: "This Is What Lipstick Inspired by Your Zodiac Sign Looks Like", "Level Up: 10 Tempting Drugstore Beauty Items That Only Look Expensive" [Cosmopolitan], "11 Beauty Looks We Loved At The SAG Awards 2018", "Read My Lips: Creating The Perfect Red Lip With Violette" [Vogue]; "20 Glitter Nail Designs for a Sparkly, Shiny, Shimmery Manicure", "13 Romantic Hairstyles to Wear on Valentine's Day" [Elle]; "Густые и блестящие: в чем польза кератина для волос"; "Умереть от красоты: 6 жутких косметических средств, котрыми пользовались раньше”; "6 вредных привычек для кожи, которые нужно бросить к 30 годам" [Cosmopolitan]; "5 продуктов, которые не стоит есть натощак"; "Как заботиться о коже губ летом?”, “Топ-5 продуктов, которые нельзя есть после тренировки” [Elle].

The topic of "Fashion" is also characterized by the vocabulary characteristic of the fashion industry: "10 Pairs of White Sneakers That Go With Everything", "10 Camel Coats 
That Will Never Go Out of Style”, "The Shoes You Won't Regret Investing In”, "30 Party Shoes That Are as Comfortable as Heels Can Get" [Elle]; "Стали известны победители конкурса дизайнеров одежды "Погляд у майбутнє"”; "Відкриття Н\&M у Києві: деталі очікуваної подій, "30 вещей, которые должны бать в гардеробе к 30 годам” [Cosmopolitan]; "Названі переможчі Всеукрайнського конкурсу молодих дизайнерів "Погляд у майбутнє"”; "15 модных советов от Дюсорджио Армани”, "Пляжный сезон: какие купальники выбирают для отпуска модели?” [Elle].

However, the XXI c. dictates its social role and today we have the opportunity to observe the woman not only in her traditional dimension of family and household duties, but also as an active player in building their careers; a person who deals with political and social issues and scandals. Today, the essence of the women's issue in the West countries and the United States can be described as the implementation of the workplace, active social position etc. Among the three magazines selected for the study headings on motherhood and family, we met only in "Cosmopolitan" magazine: "10 Things New Moms Want You to Know", "An Open Letter to My Wife After the Birth of Our Son", "10 Things Returning to Work Want You to Know". Instead "Elle" and "Cosmopolitan" widely enlightens the topics of "Love, Sex and Boyfriend": "Ask E. Jean: How to Do I End My Obsession With My Ex?" [Elle], but "Vogue" avoids such headings, specialising in fashion, beauty and self-care.

Active positions among the variety of materials are those devoted to politics. It should be noted that the women's magazine covers only those political aspects and news related to the place of women in society, social activity on this issue, a variety of protests etc. The online version of "Elle" magazine provides 2,213 links to the articles under the key phrase "Women in politics" [Elle] and 2,253 under the phrase "Women in business" [Elle]. "Vogue" and "Cosmopolitain" also actively support community initiatives to protect women in society and fight for their rights: "All the best celebrity Instagrams from the 2018 Women's March" [Cosmopolitan], "The Role of Protest In 2018: Six Women Weigh In" [Vogue].

Based on the thematic contents of the women's glossy magazines, we consider that 8 certain basic blocks are the main slots that make up the conceptual structure of the concept frame "modern woman" in the most important languages. Schematically, they can be represented as follows:

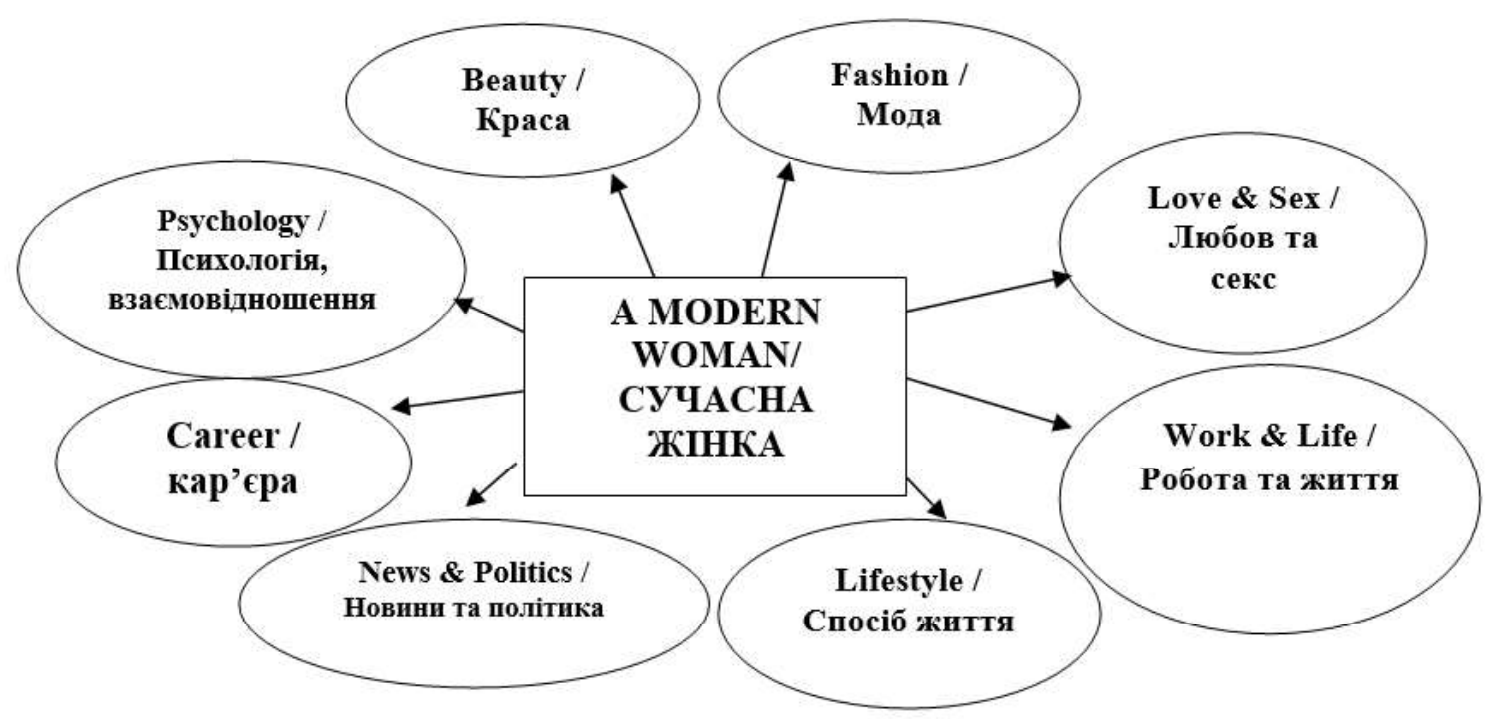

Scheme 1. "A Modern Woman" Frame Components 


\subsection{Concept-Script in Related Languages.}

In order to characterise structures of knowledge representing the sequence of events associated with causal connections, the term script or scenario was introduced and further developed by Schenk and Abelson by analogy with the frame of Minsky (Minsky, 1979). A script or scenario is defined as "a set of expectations about the development of events, a type of structure of consciousness, assimilated by experience and directs human behaviour in a specific typical, predictable situation or context" (Concise Dictionary of Cognitive Terms, 1996), "an effective stereotype" of human knowledge (Schenk, Abelson, 1977), a sequence of stereotyped episodes with a sign of development (Babushkin, 1996) etc., it is tied to a specific situation and concerns all options for its development in general (Krasnih, 2002).

T. Behta shows that scenarios (scripts) are divided into three categories: situational (restaurant, bus); personal (to be obsequious, to be a spy); instrumental (light a cigarette, start the car). They may have their own links, which are different but related examples one of the general category. For example, the researcher presents that the links of the scenario (script) restaurant can be called: a fast-food restaurant, an Italian restaurant, a coffee bar. Scenario (script) the restaurant has different "meanings" depending on the point of view of its participants (visitor, waiter, owner). There are slots-episodes in the scripts: offers, roles of participants, starting conditions, results, scenes and their sequence. The scenario (the script) of the court from the point of view of a judge proposal is: wig, hammer; roles of accused, the lawyer, judges, witnesses; starting point is the purpose of the hearing; the result is punishment or acquittal of the defendant; the scenes are charges, an official statement by the lawyer, the statement of the lawyer (Behta, 2011). Considering this, we agree that the scenario (script) is rather an example of a specificity but not of a general knowledge, and even though it was connected with the general plans and purpose may occur despite them. Scenario (script) depends on personal experience and can change within one person.

Let's consider this onto the example of scenario "a visit to the parents" of the main character Lucy from the art works of contemporary British writer Cecilia Ahern "The Time of my Life" and its translations into Russian and Ukrainian languages.

Episode one: the road to the parents' house:

(eng.) 'The route to me parents' house was a tricky system of windy narrow roads in Glendalough that dipped and rose, twisted and turned around one giant mansion after another" (Ahern: 20).

(rus.) "Путь к дому родителей крут и извилист. Узкие продуваемые ветром дороги Глендалоха ныряют вниз и взмывают вверх, кружат, огибая путаным лабиринтом один огромный особняк за другим" (Ахерн: 26).

(ukr.) “Дорога до будинку мойх батьків - то плутана система покручених вузьких доріг у Глендалогу, що то підіймалися, то пірнали вниз, обкручувалися й оберталися після одного велетенського особняка, потім після іншого” (Агерн: 27).

Metaphorisation in this case is marked by figurative meanings of the verbs (англ.) to dip - to put something into liquid for a short time - to go down to a lower level [CALD]; (рос.) нырять - резким движением погружаться в воду с головой - плывя (или летя, двигаясь), покачиваться взад и вперед [ТСРЯ]; (укр.) пірнати - занурюватися у воду з головою - пересуваючись по землі, швидко спускатись (у сніг, вибоїну тощо) [ATСУМ], which is characterized by the replacement of archeseme "to put into", «погружать», “занурюватися" onto "to go down", "двигаться", "пересуватися" and addition of new differential semes "lower level", "взад / впред", "спускатись". The logicalsemantic implementation of this example is as follows: humain $\rightarrow$ inanimate notion (action) + logical multiplication (conjunction: $a^{\wedge} b$ ).

Episode two: arrival to the parents' house: 
(eng.) "The fact that I was waiting outside, pending permission to be granted, detached me from it even more" (Ahern: 19).

(rus.) "Тот факт, что я вынуждена была торчать у ворот, пока их созволят открыть, подчеркивал нашу разобщенность с этим местом” (Ахерн: 25).

(ukr.) "Той факт, щзо я мусила чекати зовні, коли мені дозволять увійти, підкреслював для мене ще більш його сторонність" (Агерн: 26).

Reinterpretation of the verbs (eng.) to detach - to separate or to remove something else that is connected to - no to show any emotional involvement or interest in a situation [CALD]; (rus.) подчеркивать - провести черту под чем-то - особо выделить, обращая внимание на что-нибудь [ТСРЯ]; (ukr.) підкреслювати - проводити риску під якимнебудь текстом, словом і т. ін., виділяючи щось - виявляти своє ставлення до кого-, чого-небудь, поведінкою, діями тощо [АТСУМ] was due to the semantic transformation of the replacement of archisemes "to separate", "проводить черту", "проводити риску" onto "not to show", "выделять", "виявляти" and the addition of new differential semes "emotional involvement", "interest", "внимание", "ставлення". The logical-semantic model of this transference is as follows: human (action) $\rightarrow$ abstract concept (emotional state) + logical multiplication (conjunction: $a^{\wedge} b$ ).

Episode three: meeting with family and parents:

(eng.) "The door opened and my brother Riley grinned out at me like a Cheshire Cat" (Ahern: 23).

(rus.) “Дверь распахнулась, и в проеме возник братеи Райли, ухмыляясь, как Чеширский Kom” (Ахерн: 29).

(ukr.) “Двері відчинилися, $і$ мій брат Райлі всміхнувся до мене, як Чеширський Kim” (Агерн: 29).

The character of the smile of the heroine's brother in the third episode is transmitted by the comparison of a precedential nature. The cat demonstrates unusual abilities for an animal in Lewis Carroll's famous fairy tale: he can speak, smile and slowly disappear into space, in such a way that there is only one smile that freezes in the air at the end. But the image of the Cheshire Cat comes from the English proverb to grin like a Cheshire Cat meaning "to smile sardonically". Compare the original and derived meaning of verbs in (eng.) to grin - to smile a wide smile - to accept something bad without complaining [CALD], (rus.) ухмыляться - слегка засмеяться (обычно с насмешкой, недоверчиво) [ТСРЯ] and (ukr.) всміхатися - усмішкою виявляти певні почуття (радість, задоволення тощо) - сприяти, допомагати кому-небудь в успіху, удачі; обіцяти щось приємне, радісне [АТСУМ]. The logical-semantic implementation of this example is as follows: animal (appearance) $\rightarrow$ human (appearance, character) + logical multiplication (conjunction: $\left.a^{\wedge} b\right)$.

Episode four: family dinner:

(eng.) "The they gorged on a couple of pheasant legs, clinked pewtered jugs, groped a boob or two, wiped their drooling mouths and burped - or at least I imagined them do that - and then they sat" (Ahern: 34).

(rus.) "Потом они в момент проглотили по фазаньей ножке, сдвинули оловянные кружки, облапали парочку девиц за сиськи, утерли лоснящиеся губы и дружно рыгнули - так мне, по крайней мере, привиделось, - а затем уселись за стол", (Ахерн: 40).

(ukr.) "Потім вони проковтнули по фазанячій ніжчі, почаркувалися олив'яними кухлями, обмацали циџьки у двох або трьох служнищь, утерли губи, які блищали від жсиру, й ригнули - чи так принаймні мені здалося, - а тоді посідали за стіл" (Агерн: $38)$. 
The metaphor in the fourth episode of the family dinner is based on the transference of original and derived notions in (eng.) to gorge - to eat until you are unable to eat any more - to consume about something pleasant, tasty etc. [CALD]; in (rus.) проглотить глотая, пропустить изо рта в пищевод - поглощать (о чем-нибудь приятном, вкусном и т.д) [ТСРЯ] and (ukr.) проковтнути - ковтаючи, пропускати через стравохід у шлунок; робити ковток - поглинати (про щось дуже смачне або їстівне) [АТСУМ], which is implemented in the replacement of archisemes "to eat", "глотать", "ковтати" and addition new differential semes "smth. pleasant", "tasty", "что-то приятное", "вкусное", "щось приємне", "смачне", "істивне". The logical-semantic model of this transfer is as follows: human (character trait) $\rightarrow$ abstract notion (emotional state) + logical multiplication (conjunction: $\left.a^{\wedge} b\right)$.

\subsection{Concept-Scheme in Related Languages.}

Another structure of knowledge representation the scheme is qualified by Boldyrev (2000) as "a mental image of an object or phenomenon having a spatially and contoured character". It is considered that the scheme can be drawn, which indicates the reality of the existence of this form of structuration of knowledge (for example, a schematic representation of a person: head, corps, arms, legs). Klimova agrees with him (2011), adding to the spatially and contoured graphic mental image (general contours, schematic representation) that this is an intermediate level of abstraction between the representation and the concept.

The impetus for the development of Minsky's (1979), Winograd's (1976), Schank and Abelson's (1977) schematic ideas was the theory of schemes by Bartlet (1951), which put forward by the famous British psychologist in cognitive studies in 30-e years of the XX century. He used drawings, figures and prose fragments etc. as experimental material in his empirical studies. According to Schank and Abelson's theory (1977) understanding is achieved with the help of diagrams. The concept of schemes is considered as the usage of mental representation of typical situations, images in the processing of discourse for the prediction and understanding of a particular example given in discourse. Schemes are activated from memory or key linguistic units of text, or context, and help to understand discourse. Schemes are stereotypical models, so each time they are "applicable" to the understanding of a particular discourse by its recipients (Cook 1995: 80). They are involved into the process of interpretation and help to correlate specific experiences and actions with mental representations, highlight the scheme of the situation, causing the relationship between the participants and the circumstances of the situation (Concise Dictionary of Cognitive Terms, 1996: 179-180). This mental model, which organizes the experience, helps to interpret it, breaking it into episodes (Chief, 1983: 41-43). Compared to scenarios, schemes have weaker capabilities because they are seen as organized prior knowledge that leads to expectations or anticipations of aspects in the interpretation of discourse. According to G. Lakoff (2004), image-schemes structure our experience onto pre-conceptual level, they are motivated and metaphorical units that form an integral part of the everyday human experience, which is based on physical sensations. According to Bystrov (2016: 62-63), in terms of a metaphorical reinterpretation of the data empirically obtained by the individual, the most researched image-schemes are the container scheme, the part / whole scheme, the link scheme, the centre / periphery scheme, the front / back orientation scheme, the up / down scheme etc.

Thus, examples of metaphors with a spatial reference point "up / down", "вгору / вниз" reflect and generalise good / positive or bad / negative in person's life. This is vividly represented in the metaphors that reflect the emotional state of the main character Lucy 
during the meeting with her Life in the novel of a modern English writer Cecilia Ahern "The Time of my Life" and its translations into Russian and Ukrainian.

As for positive, it is expressed in metaphors where vocabulary prevails with the meaning of increase, rise, etc.:

(eng.) "I like coffee, it makes me happy in the small way that things you like can lift you, so I figured a café would mean I was with something that lightened my mood" (Ahern: $71)$.

(rus.) "Я люблю кофе, и меня радуют приятные мелочи жизни, они подыммают настроение” (Ахерн: 77).

(ukr.) "Я люблю каву, вона тішить мене у той самий спосіб, у який речі, щуо вам до вподоби, можуть поліпшити вам настрій, $і$ тому я вирішила, щзо зайшовши до кав'ярні, я потраплю до компанії, а кава означатиме, я матиму щуось таке, що завжди піднімає мій настрій " (Агерн: 68).

Metaphorical transference is marked from the semantic point of view by the replacement of archisemes "to become", "взяти нагнувшись", "брати нахилившись" onto "to cause", "улучшить", "поліпшити" in languages that are researched (eng.) to lighten - to become less dark - to (cause) to become happier and less worried [CALD], (rus.) nodblмamb - нагнувшись, взять (лежащее внизу, уроненное, брошенное) - наладить, улучшить, развить [ТСРЯ]; (ukr.) nіднімати - нахилившись, брати, підібрати, підбирати з землі, підлоги, знизу і т. ін. - створювати сприятливі умови, поліпшувати, допомагати розвиткові чого-небудь [АТСУМ]. The logical-semantic model of this transference is as follows: physical phenomenon $\rightarrow$ human (emotional state) + logical multiplication (conjunction: $a^{\wedge} b$ ). slowdown:

And all negative is marked with the lexical set, which generalizes the decrease or

(eng.) "If Life had tried to meet with me two years ago, I was falling but now, not any more. I'd fallen from a great height and was wedged into what some way assume was a rather precarious place that could easily snap and break and send me falling again, but I was very happy, cosy even, and everything was fine, absolutely fine" (Ahern: 70).

(rus.) "Если бы Жизнь встретился со мной два года назад, я бы с ним согласилась. Тогда мне казалось я падаю в пропасть, но теперь нет, теперь ни за что. Я свалилась с огромной высоты и приземлилась на свое место. Кому-то, возможно, мое положение кажется ненадежным и шатким. Но мен очень уютно, удобно и хорошо” (Ахерн: 76).

(ukr.) "Якби Життя зробив спробу зустрітися зі мною два роки тому, я його зрозуміла б, бо відчувала тоді, що падаю в порожнечу, але тепер ні. Я вже впала 3

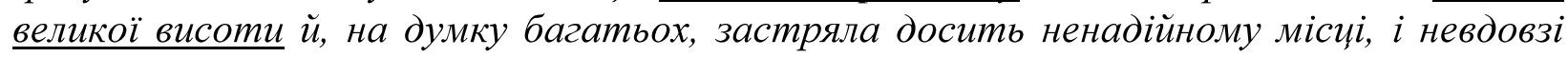
знову полечу вниз, але я почувала себе щасливою, мені було навіть затишно у моєму новому існуванні, й усе було чудово, абсолютно чудово" (Агерн: 67).

This metaphorical transference is the typical the semantic model of replacing the archiseme "move down", "опускаться", "спускатися" onto "to be beaten", "to be defeated", "терпеть поражение", "потерпіти поразку" with the loss of differential semes "onto the ground", "вниз", "вниз" (eng.) to fall - to move down suddenly onto the ground suddenly onto the ground or towards the ground without intending to or by accident - to be beaten or defeated, to look unhappy or disappointed [CALD]; (rus.) naдать - непроизвольным движением резко опускаться сверху вниз; опускаться, валиться на землю, книзу терпеть поражение [ТСРЯ]; (ukr.) naдати - переміщатися, валитися, спрямовуватися і т. ін. зверху вниз під дією ваги - втрачати (віру, надію і т. ін.); потерпіти поразку 
[АТСУМ]. The logical-semantic scheme of this transference is as follows: physical action $\rightarrow$ human (emotional state) + logical multiplication (conjunction: $a^{\wedge} b$ ).

\section{Conclusions.}

Summing up, we would like to note that the concept as a basic mental unit of human Random Access Memory, which structures the mental space of a person is a cognitive and semantic universal onto the cognitive level while forming lexical meaning in such related languages as English, Ukrainian and Russian. And, consequently, such types as prototype, frame, script and scheme etc. can also be considered cognitive and semantic universals. This is clearly demonstrated within the analysis of the categorical structure of the concept of "modern woman" in the languages studied.

\section{References}

Babushkin, A. P. (1996). Tipy konzeptov v leksiko-phrazeologicheskoi semantike yazika [Types of Concepts in Lexico-phraseological Semantics of Language]. Voronezh: Voronezhskiy gosugarstvenniy Universitet.

Bartlett, F. C. (1951). The Mind at Work and Play. London: George Allen \& Unwin. American edition: Boston, Beacon Press.

Behta, T. O. (2011). Rol mentalnih modeley u kognitivnomu opratsuvanni tekstu [The Role of mental models in Cognitive Processing of the Text]. Nova Philologia, 45. P. 15-18.

Boldyrev, N. N. (2000). Kognitivnaya semantika [Cognitive Semantics]. Tambov.

Bystrov, Ya. V. (2016). Anglomovniy biographichniy narativ $u$ vimorah kogntivnoy lingvistiki $i$ sinegetiki: monographia [English Biographical Narrative in the Scope of Cognitive Linguistics and Synergetics: monograph]. K., Ivano-Frankivsk.

Chief, U. L. (1983). Pamyat i verbalizatsia proshlogo opita [Memory and Verbalization of the Past Experience]. Novoe v zarubezhnoi lingvistike, 12. P. 35-74.

Cook, G. (1995). Discourse and Literature: The Interplay of Form and Mind. OUP.

Demyankov, V. Z. (2001). Ponyatie I konzept v hudozhestvennoy literature i nauchnom yazike [Notion and Concept in Fiction and Scientific Language]. Voprosi philologii, 1. P. 35-47.

Fillmore, Ch. (1982). Frame semantics. The Linguistic Society of Korea (ed.) Linguistics in the Modern Calm. P. 11-137.

Fillmore, Ch. J., Baker, C.A. (2010). Frames Approach to Semantic Analysis. In The Oxford Handbook of Linguistic Analysis. eds B. Heine, H. Narrod. P. 313-340.

Goffman, I. (2004). Analiz freimov: esse ob organizatsiy povsednevnogo opita [Frame Analysis: the Essay about the Organization of Everyday Experience]. Moscow : RAS. FOM.

Hamray, O. O. (2008). Invarianti, prototipi I paprdgmi arabskoi grammatiki [Invarians, Prototypes and Paradigms of Arab Grammar]. Shidhiy svit, 3. P. 143-179.

Kalina, Ya. I. (2010). Konzept "Zhinka" ta stereotipni uyavlenna pro yiyi sotsialnu rol v nemetskom anekdoti [Concept "Woman" and Stereotypical Conception about its Social in German Everyday Anecdote]. Visnik Zaporizkogo Natzionalnogo Univesitetu, 2. P. 25-31.

Klimova, Yu. Yu. (2011). Tipologia protsessiv konzeptualizatsii ta kategorazatzii [The Typology of the Processes of Conceptualization and Categorization]. Retrieved from: http://archive.nbuv.gov.ua/portal /natural/nvvnu/filolog_mov/2011_3_1/R1/Klimova.

Kolyadenko, O. O. (2013). Termin "Freim" u lingvistitzi [The Trem "Frame" in Linguistics]. Terminologichniy Visnik, 2(1). P. 139-144.

Krasnih, V.V. (2012). Etnopsyholingvistika i lingvokulturologia [Ethnopsycholinluistics and Linguaculturology]. Moscow : Gnosis.

Kutzik, O., Kolechko, M. (2015). Konzeptualizatia obraza zhinki v ukrainskiy ta rosiyskiy paemiologii [Conceptualization of the Woman's image in Ukrainian and Russian Paremiology]. Ridne slovo $v$ etimologichnomu vimiri. P. 131-140.

Lakoff, G., Johnson, M. (2003). Metaphors We Live by. London: University of Chicago Press.

Marchuk, U. V. (2009). Asotiativniy potentzial lingvokulturnih konzeptov u rizosystemnih movah: aftoreferat [Associative Potential Linguo-cultural in the Languages of Different systems]. Kiev: KNU im. T. G. Shevchenko.

Maslova, V. A. (2004). Kognitivnaya Lingvistika [Cognitive Linguistics]. Minsk : Tetra systems.

Minsky, M. (1979). A Framework for Representing Knowledge. Frame Conceptions and Text Understanding. P. 1-25. 
Popova, Z. D., Sternin Y. A. (2007). Kognitivnaya Lingvistika: uchebnoe izdanie [Cognitive Linguistics]. Moscow : ACT "Vostok-Zapad".

Rosch, E. (1973). Natural categories. Cognitive Psychology, 7. P. 328-350.

Ruduk, T. V. (2010). Verbalizatsia konzeptiv. Cholovik, Zhinka v ukrainskiy phrazeologii [Verbalization of the Concepts Man. Woman in Ukrainian Phraseology]: Thesis. Kiev.

Schank, R. C., Abelson, R. (1977). Scripts, Plans, Goals and Understanding. Hillsdate, NJ: Lawrence Erlbaum.

Selivanova, O. O. (1999). Aktualni naprayami suchasnoi lingvistiki (analitichniy oglayd): [Actual Trends of a Modern Linguistics (analytical review)]. Kiev : Fitosotziozentr.

Steptzova, A., Romah, O. V. (2009). Glayntzeviy zhurnal kak zhanr sovremennoi massovoy kulturi [Glamour Magazine as Genre of a Modern Mass Culture]. Retrieved from: https://cyberleninka.ru /.../glyantsevyy-zhurnal-kak-zhanr-sovremennoy-massovoy-ku

Voroninae, Yu. V. (2015). Konzept "Zhinka" v suchasniy cholovichiy prozi (na materiale ideolektnih porivnyan' [Concept "Woman" in Modern Man's Prose (on the material of idiolect similes)]. Movoznavchiy Visnik, 20. P. 168-172.

slovari.

Wierzbicka, A. (1996). Yazik. Kultura. Poznanie [Language. Culture. Cognition]. Moscow : Russkie

Winograd, T. (1976). Towards a procedural understanding of semantics. Revue Internationale de Philosophie, 117-118(3). P. 260-303.

Zhabotinska, S. A. (1999). Kotseptualniy analiz: typi freimov [Concept analysis: types of frames]. Visnik Cherkasskogo Universitetu, 11. P. 12-25.

\section{List of Illustrative Sources}

Ahern, C. (2013) Chas mogo zhittay: translated from English by V. Shovkun. Kharkiv: Knizhkoviy klub "Klub Simeynogo dozvillya".

Ahern, C. (2017) Vremya moiej zhizni: translated froom English by L. Gurbanovskaya. M.: Inostranka, Azbuka-Attikus.

Ahern, C. (2011). The Time of My Life. Harper Collins Publishers.

\section{List of Lexicographic Sources}

CALD - Cambridge Advanced Learner's Dictionary. Access: www.cambridge.es/en/catalogue $/$ dictionaries/.../cald

Kratkiy slovar kognitivnih terminov [Concise Dictionary of Cognitive Terms] (1996). E. S. Kubryakova, B. Z. Demyankov, U. G. Pankrats, L. G. Lusina. Moscow.

ATCУM - Academichniy tlumachniy slovnik ukrainskoi movi. Access: https://sum.in.ua/s/tlumachnyj

TCPЯ - Tolkoviy slovar russkogo yazika S.I. Ozhegova. Access: https://slovarozhegova.ru/

\section{Bibliographic Description:}

Балабан, О.О. (2019). Концепт Сучасна Жінка як когнітивно-семантична універсалія у споріднених мовах. Науковий часопис Національного педагогічного університету імені М. П. Арагоманова. Серіл 9. Сучасні тенденції розвитку мов, 19. C. 17-35. DOI: https://doi.org/10.31392/NPU-nc.series9.2019.19.02

\section{Анотація}

Запропонована зіставно-типологічна розвідка представляє опис конщепту Сучасна Жінка як когнітивно-семантичної універсалії у споріднених мовах. Це здійснено завдяки опису макроструктури конщепту, що передбачає розподіл виокремлених ознак за структурними макрокомпонентами концепту - образного, інформаційного та інтерпретаційного; за категоріальною структурою конщепту, де виявлена ісрархія когнітивних класифікаційних ознак, що концептуалізують відповідний предмет або явище; за польовою організачією конџепту.

Базуючись на типології конщептів, запропонованій Й. А. Стерніним, який виділяс три основні типи конщептів: концепти-уявлення, поняття та гештальти, здійснено спробу визначити категоріальну структуру цього концепту як прототипу, як фрейму, як сиенарію / скрипту та як схеми в споріднених мовах на прикладі художнього твору сучасної англійської письменнииі Сесілії Атерн "Тһе Time of my Life" / "Время моей жизни" / "Час мого життя" та їі перекладів російською та украйнською мовами. 
Визначено когнітивні класифікаційні ознаки для конщепту-прототипу “сучасна жінка" $у$ споріднених мовах. Зафіксовано, що фізіологічні ознаки маркують конщептуальні ознаки біологічної статі, віку, зовнішності; статусно-рольові ознаки вказують на сочіальне положення, статус та роль у суспільстві; функціональні ознаки позначають вид діяльності або рід занять; релячійні ознаки позичіонують людину по відношенню до інших осіб або групи осіб; ментально-функціональні ознаки вказують на емочійний стан, розумові здібності, стан здоров'я тощо; аксіологічні ознаки характеризують внутрішні властивості людини, риси характеру, манеру поведінки; афективноемотивні ознаки свідчать про емоиійне відношення до суб'єкта: схвалення-осуд / невдоволення, прийняття-неприйняття, роздратування, іронія тощзо. Основними слотами концепту-фрейму “сучасна жінка" є краса, мода, любов і секс, робота та життя, спосіб життя, новини $і$ політика, кар'єра, психологія і взаємостосунки. Концепти-сиенарії та концепти-схеми також представлені відповідними епізодами та образами. Отже, кониепт сприймаємо як базову ментальну одиницю оперативної пам 'яті людини, яка структурує ментальний простір людини, є когнітивно-семантичною універсалією когнітивного рівня при формуванні лексичного значення в таких споріднених мовах, як англійська, украӥнська, російська.

Ключові слова: конщепт, сучасна жінка, конщеепт-прототип, конщепт-фрейм, концепт-сценарій (скрипт), концепт-схема, когнітивно-семантична-універсалія. 